\title{
KERANGKA KERJA VAL IT 2.0 SEBAGAI ALAT PENGUKURAN INVESTASI TEKNOLOGI INFORMASI
}

\author{
Rita Komalasari, S.Si.,M.Kom \\ Program Studi Manajemen Informatika \\ Politeknik LP3I Bandung \\ Jl.Pahlawan No. 59 Bandung, Indonesia \\ E-Mail : ritakomalasarilp3i@ rocketmail.com
}

\begin{abstract}
Abstrak : Justifikasi investasi Teknologi Informasi (TI) merupakan keahlian penting bagi siapa saja yang bekerja di bidang teknologi. Sementara banyak keputusan investasi TI dilakukan oleh pemimpin dalam organisasi TI, kerap usulan untuk peralatan atau layanan baru datang dari staf IT. Sangat penting untuk memahami terminologi dan teknik dasar untuk membuat suatu kasus untuk berinvestasi dalam peralatan baru.
\end{abstract}

Tulisan ini akan memberikan ketrampilan dasar yang diperlukan untuk menganalisa dan membuat penilaian untuk investasi TI yang diusulkan. Selanjutnya untuk memperoleh hasil dan manfaat yang maksimal bagi organisasi dalam melakukan pengembangan teknologi dibutuhkan suatu pertimbangan yang matang sebagai framework untuk menghitung nilai keuntungan, dan salah satunya adalah Val IT.

Pendekatan interpretasi melalui Val IT digunakan untuk memberikan gambaran yang jelas mengenai aset teknologi informasi pada suatu organisasi. Val IT terdiri dari sekumpulan prinsip dasar dan sejumlah proses yang didasari oleh, prinsipprinsip tersebut, selanjutnya diturunkan menjadi sekumpulan manajemen praktis utama. Untuk dapat menerapkan business case yang dapat diterapkan pada proyek teknologi informasi tertentu, yang nantinya digunakan sebagai alat bantu untuk merencanakan, mengukur,dan memantau aset teknologi informasi. Business case merupakan sasaran untuk memberikan gambaran yang jelas kepada pihak manajemen atas manfaat pengembangan teknologi sebagai aset perusahaan dan membantu manajemen dalam membuat keputusan mengenai aset tersebut.

Keywords : Investasi TI, Val IT, Business Case

\section{Pendahuluan}

TI memberikan manfaat bagi perkembangan proses bisnis perusahaan dalam rangka peningkatan produk dan layanan, investasi di bidang teknologi informasi (TI) sudah menjadi strategi penting bagi perusahaan untuk meningkatkan kualitas produk dan layanan mereka (Didem Demirhan et al. Winter 2005-2006), dimana perkembangan bisnis tersebut banyak mengalami tantangan perubahan termasuk dalam perubahan kemajuan TI, yang didalamnya terdapat segi finansial, persaingan bisnis dengan adanya pendatang baru, pelanggan dan para pengguna TI lainnya. 
Perusahaan harus menyadari bahwa mereka tidak berinvestasi dalam TI - mereka berinvestasi dalam TI yang mudah mengalami perubahan. Jika perusahaan menyadari potensi penuh dari TI - yang mudah mengalami perubahan, tatakelola TI harus merupakan bagian integral dari keseluruhan tatakelola organisasi perusahaan. Perusahaan yang memahami hal ini dan melaksanakannya dengan baik akan menjadi yang terdepan dalam bisnis mereka (John Thorp, 2006). Selanjutnya perusahaan perlu memiliki strategi yang efektif mengenai pemanfaatan TI yang dimilikinya sebagaimana diungkapkan oleh Heather A. Smith et, al 2007 dalam kesimpulan jurnalnya, pengembangan strategi yang efektif menjadi hal penting bagi organisasi saat ini.

Ketika dampak dari TI telah berkembang dalam organisasi, strategi TI tersebut akhirnya mendapatkan perhatian yang layak dalam bisnis. Namun demikian, sebagian besar organisasi masih dalam tahap belajar yang sangat awal mengenai bagaimana mengembangkan strategi TI yang efektif dan menyinkronkannya dengan strategi bisnis secara keseluruhan. Untuk mendapatkan keseimbangan yang tepat antara berbagai cara TI dapat dimanfaatkan untuk mempengaruhi bisnis merupakan tantangan konstan bagi para pemimpin saat ini. Meskipun ada, strategi TI belum dikembangkan dengan baik, terdapat pemahaman bersama pada beberapa critical success factor dan elemen kunci yang terlibat. Seiring waktu, kemungkinan besar akan disempurnakan dan menjadi lebih baik serta terintegrasi dengan pengembangan strategi bisnis secara keseluruhan.

Ada banyak metode untuk membantu dalam mengevaluasi investasi IT. Hal ini sangat tergantung pada jenis investasi yang dibuat dan kematangan organisasi TI dalam mengevaluasi modal pembelian. Ukuran organisasi juga bisa berperan. Namun perlu diingat ini adalah sesuatu yang tidak memerlukan banyak waktu dan bahkan untuk sebuah organisasi kecil menengah, upaya melalukan evaluasi investasi teknologi ini akan dihargai. Selanjutnya akan dibahas teknik evaluasi investasi TI menggunakan Val IT 2.0.

\section{Investasi Teknologi Informasi}

Secara sederhana teknologi informasi dapat dikatakan sebagai ilmu yang diperlukan untuk mengelola informasi agar informasi tersebut dapat dicari dengan mudah dan akurat. Isi dari ilmu tersebut dapat berupa teknik-teknik atau prosedur yang menyimpan informasi secara efisien dan efektif menggunakan piranti teknologi informasi. Telaah terhadap piranti teknologi informasi ini dijelaskan oleh Haag dan Keen dalam Abdul Kadir dan Terra Ch Triwahyuni (2003:2) bahwa teknologi informasi adalah seperangkat alat yang membantu Anda bekerja dengan informasi dan melakukan tugas-tugas yang berhubungan dengan pemrosesan informasi. Demikian pula dengan apa yang disampaikan oleh William dan Sawyer (2003) yang dikutip Abdul Kadir dan Terra Ch Triwahyuni (2003:2) dalam bukunya Pengenalan Teknologi Informasi mengemukakan bahwa teknologi informasi adalah teknologi yang menggabungkan komputer dengan jalur komunikasi berkecepatan tinggi yang membawa data, suara dan video.

Namun, teknologi adalah pedang bermata dua - yang bukan hanya sekedar sumber keunggulan kompetitif, tetapi juga dapat menjadi sumber gangguan dalam 
kompetisi organisasi. Sebuah studi terbaru oleh perusahaan konsultan McKinsey menyimpulkan bahwa para eksekutif merasa bahwa perusahaan yang paling rentan terhadap ancaman tiga teknologi memungkinkan:

1. pergeseran ekspektasi pelanggan untuk penawaran yang lebih baik atau membedakan

2. perubahan signifikan dalam produk dan pelayanan biaya dan

3. munculnya produk baru atau layanan dari pesaing.

Satu-satunya cara untuk mencegah kompetisi organisasi terganggu adalah menempuh agenda teknologi informasi agresif sendiri. Pendekatan seperti itu tidak hanya akan memberikan keunggulan kompetitif yang dibutuhkan untuk tumbuh, tetapi juga akan memastikan organisasi bukan yang akan terganggu. Tetapi mengingat peluang besar dalam berinvestasi di TI, bagaimana cara menentukan bagaimana investasi yang didahulukan? Tulisan ini, akan menjelaskan kerangka sederhana namun terbukti untuk membantu membuat keputusan prioritas.

Selama bertahun-tahun tim manajemen organisasi telah berjuang untuk mencapai baik profitabilitas jangka pendek dan kelangsungan hidup jangka panjang dan perkembangan melalui investasi TI mereka. Biasanya, mereka mengharapkan profitabilitas dari aplikasi bisnis baru dan menganggap infrastruktur TI sebagai sesuatu yang diperlukan untuk kelangsungan hidup dan pertumbuhan jangka panjang Layanan infrastruktur seperti sistem yang terintegrasi, akses data dan jaringan yang aman kini penting untuk profitability jangka pendek (Benaroch and R. Kauffman, 2000:70-86). dan pertumbuhan jangka panjang dan kelangsungan hidup tergantung pada pengembangan aplikasi bisnis yang menguji peluang bisnis yang muncul. (E.K. Clemons, 1991 :22-36).

\section{Kerangka Kerja Val IT 2.0}

Kerangka Val IT berkaitan erat dan melengkapi COBIT ® yang merupakan salah satu produk dari ITGI yang menyediakan kerangka kerja yang komprehensif untuk layanan pengiriman informasi berbasis teknologi berkualitas tinggi (berbasis TI). Sementara COBIT menetapkan good practices untuk sarana memberikan kontribusi bagi proses penciptaan nilai, Val IT menetapkan good practices untuk proses akhir, dengan menyediakan perusahaan, struktur yang mereka butuhkan untuk mengukur, memantau dan mengoptimalkan realisasi nilai bisnis dari investasi di bidang TI. Val IT melengkapi COBIT dari perspektif bisnis dan keuangan, dan akan membantu bisnis atau profesional TI yang berminat dalam evaluasi dari nilai investasi TI.

The Val IT Kerangka menyajikan proses dan praktek manajemen kunci untuk tiga domain yaitu Value Governance, Manajemen Portofolio dan Manajemen Investasi. Val IT mengambil cara pandang tata kelola perusahaan. Hal ini membantu para eksekutif untuk fokus pada dua dari empat dasar pertanyaan governance yang berkaitan dengan IT (gambar 1): 'Apakah kita melakukan hal yang benar?' (Pertanyaan strategis) dan 'Apakah kita mendapatkan manfaat?' 
(Pertanyaan value). COBIT, di sisi lain, mengambil pandangan TI, membantu eksekutif fokus pada menjawab pertanyaan-pertanyaan 'Apakah kita melakukannya dengan cara yang benar?' (Pertanyaan arsitektur) dan 'Apakah kita mendapatkan mereka dilakukan dengan baik?' (Pertanyaan delivery). (John Thorp, 2003)

The strategic question. Is the investment: - In line with our vision

- Consistent with our business principles

- Contributing to our strategic objectives

- Providing optimal value, at affordable cost, at an acceptable level of risk

The architecture question. Is the investment

- In line with our architecture

- Consistent with our architectural principles

- Contributing to the population of ou

architecture

- In line with other initiatives

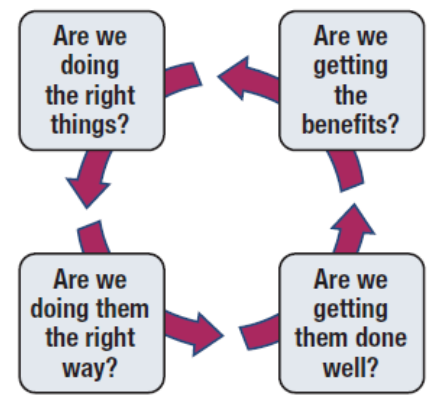

The value question. Do we have:

- A clear and shared understanding of the

expected benefits

- Clear accountability for realising the benefits

- Relevant metrics

- An effective benefits realisation process over

the full economic life cycle of the investment

The delivery question. Do we have:

- Effective and disciplined management, delivery

and change management processes

- Competent and available technical and business

resources to deliver:

- The required capabilities

- The organisational changes required to

leverage the capabilities

Gambar 1. The Four Ares

(Sumber : The Val IT Framework 2.0 Extract, 2008:14)

Perusahaan yang menerapkan prinsip-prinsip, proses dan praktek yang terkandung dalam Val IT dapat mencapai satu set manfaat strategis serta menciptakan tingkat lebih tinggi dari nilai bisnis yang nyata. Pada level fundamental, kerangka kerja ini membantu para pengambil keputusan meningkatkan pemahaman mereka tentang sifat nilai dan bagaimana ia diciptakan; mendapatkan transparansi biaya, risiko dan manfaat membuat keputusan manajemen yang lebih tepat.

Val IT membantu perusahaan meningkatkan kemungkinan memilih investasi dengan potensi tertinggi untuk menciptakan nilai. Val IT juga meningkatkan kemungkinan keberhasilan melaksanakan investasi yang dipilih, baik ketika layanan TI sedang dibuat atau ditingkatkan, dan selama penyediaan berikutnya dan penggunaan layanan tersebut. Kerangka kerja ini mengurangi biaya dan nilai kebocoran dengan membantu memastikan bahwa pengambil keputusan tetap fokus pada apa yang mereka harus lakukan dan mengambil tindakan korektif sejak dini terhadap investasi yang tidak memberikan nilai sesuai dengan potensi yang diharapkan. Pada saat yang sama, kerangka kerja ini mengurangi risiko kegagalan, terutama yang berdampak tinggi. Kerangka kerja ini juga meningkatkan nilai bisnis, mengurangi biaya yang tidak perlu, dan meningkatkan keseluruhan tingkat kepercayaan IT pada bagian dari pimpinan tertinggi orgamisasi, manajemen eksekutif dan pemimpin organisasi lainnya.

Terdapat sejumlah istilah yang digunakan dalam kerangka kerja Val IT :

1. Project: Sekumpulan aktivitas yang berfokus untuk menghasilkan kemampuan tertentu (yang diperlukan untuk mencapai hasil bisnis berdasarkan jadwal dan anggaran yang sudah ditetapkan.

2. Portfolio: Kelompok program, proyek, layanan atau aset yang dipilih, dikelola dan dipantau untuk mengoptimalisasi pengembalian nilai dari bisnis.

3. Programme: Sebuah kelompok terstruktur yang terdiri atas berbagai proyek yang saling terkait, yang semuanya dianggap penting dan diperlukan untuk 
mencapai sasaran bisnis dan menghasilkan nilai. Proyek ini dapat meliputi tetapi tidak terbatas pada perubahan cara bisnis, proses bisnis, pekerjaan yang dilakukan orang, kompetensi yang diperlukan untuk menyelesaikan pekerjaan, teknologi mendukung dan struktur organisasi. Program investasi adalah unit utama investasi dalam Val IT.

\section{Domain dalam Val IT}

Untuk memenuhi nilai tujuan manajemen Val IT uang memungkinkan perusahaan untuk mewujudkan nilai yang optimal dengan biaya investasi yang terjangkau dengan tingkat risiko yang dapat diterima dari investasi IT-enabled, prinsip Val IT harus diterapkan dalam tiga domain:

\section{Value governance (VG)}

Tujuan Value Governance adalah memungkinkan pengelolaan nilai investasi selama kelangsungan hidup dari investasi tersebut. Sebuah komitmen dari value governance untuk membatu organisasi :

a. Melaksanakan kerangka kerja tata kelola untuk value management yang secara utuh terintegrasi dengan tata kelola organisasi.

b. Menyediakan arah strategis bagi keputusan untuk berinvestasi.

c. Mendefinisikan karakteristik dari portofolio yang diperlukan untuk mendukung investasi baru dan menghasilkan pelayanan TI, aset dan sumber daya lainnya.

d. Meningkatkan value management secara berkelanjutan.

\section{Portfolio Manajement (PM)}

Tujuan dari portfolio management adalah memastikan portofolio dari investasi berbasis TI memberikan nilai secara optimal bagi organisasi. Komitmen dari portfolio management membantu organisasi untuk :

a. Menetapkan dan mengelola profil sumber daya

b. Mendefinisikan batasan investasi.

c. Mengevaluasi, prioritasi dan memilih, menunda atau menolak investasi baru.

d. Mengelola portofolio secara keseluruhan.

e. Memonitor dan mengevaluasi kinerja portofolio

\section{Investment Management (IM)}

Tujuan investment management adalah memastikan investasi berbasis TI memberikan nilai optimal, ketika pemimpin organisasi menjalankan investment management mereka meningkatkan kemampuan mereka untuk:

a. Identifikasi kebutuhan bisnis

b. Membangun pemahaman yang jelas atas kandidat program investasi

c. Menganalisis pendekatan alternatif untuk menerapkan program

d. Mendefinisikan program dan mendokumentasikan sebuah business case secara rinci termasuk menguraikan secara jelas dan terinci manfaat program tersebut bagi perusahaan selama kelangsungan hidup investasi. 
e. Menetapkan kejelasan akuntabilitas dan kepemilikan program termasuk realisasi dari keuntungan.

f. Mengelola setiap program selama siklus hidupnya, termasuk ketika program tersebut akan dihentikan

g. Memonitor dan melaporkan kinerja program

Terdapat lima Critical Success Factors yang perlu dipertimbangkan dalam Val IT (Sarah Harries and Peter Harrison, CGE IT, FCP A, 2009:12) :

a. Enlist senior executive sponsorship

Banyak upaya untuk memperkenalkan value management gagal ketika disampaikan oleh manajemen tingkat bawah ke atas tanpa dukungan dari level senior eksekutif.

b. Recognise that introducing Val IT is about behavioural change.

Memperkenalkan Val IT melibatkan lebih dari hanya mempublikasikan framework dan melakukan sesi pelatihan untuk meningkatkan kesadaran akan value IT. Hal ini adalah program besar transformasi operasional yang mempengaruhi bagaimana tata kelola TI bekerja dan perubahan cara orang berpikir, mengelola dan bertindak.

c. Chart the destination and decide where to begin.

d. Take an incremental approach.

e. Avoid bureaucracy.

\section{Business Case}

Sebuah business case yang komprehensif sangat penting untuk hasil dari program investasi. Business case berisi seperangkat asumsi tentang bagaimana value akan dicapai, asumsi yang harus

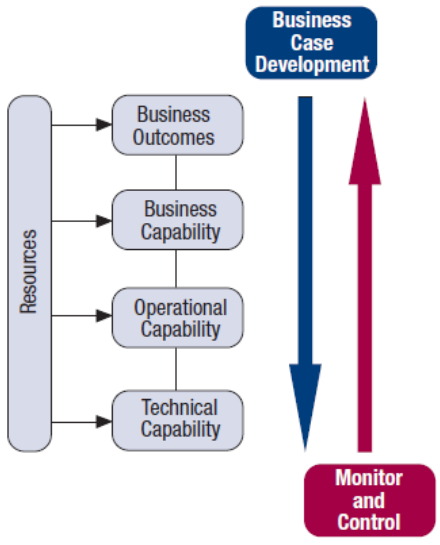

Gambar 2. The Business Case diuji dengan baik untuk memastikan bahwa hasil yang diharapkan tercapai. Business case juga harus didasarkan pada indikator kualitatif dan kuantitatif yang memperkuat asumsi ini dan memberikan pengambil keputusan wawasan yang mendukung keputusan investasi masa depan.

Business case terdiri dari masukan sumber daya utama serta tiga workstreams yang memberikan hasil (lihat gambar 2). Workstreams ini termasuk memberikan kemampuan teknis [misalnya, aplikasi customer relationship management (CRM)], kemampuan operasional (misalnya, pengguna memiliki akses untuk melengkapi informasi pelanggan) dan kemampuan bisnis (misalnya, informasi digunakan untuk mendukung cross-selling). Masing-masing dari workstreams perlu didokumentasikan dengan data untuk mendukung keputusan investasi dan proses manajemen portofolio: inisiatif, biaya, risiko, asumsi, dan hasil investasi.

Minimal, business case harus mencakup sebagai berikut:

1. Target tujuan investasi bisnis selaras dengan strategi bisnis

2. Perubahan bisnis yang diperlukan untuk menciptakan nilai tambah 
3. Investasi yang dibutuhkan untuk membuat perubahan bisnis

4. Investasi yang dibutuhkan untuk mengubah atau menambah layanan dan infrastruktur TI baru

5. TI yang berkelanjutan

6. Risiko termasuk kendala-kendala atau dependensi

7. Siapa yang akan bertanggung jawab untuk pencapaian nilai optimal dari investasi

8. Bagaimana investasi dan pencapaian nilai dimonitor sepanjang siklus hidup investasi

\section{Tahapan Business Case}

Business case harus dikembangkan dari perspektif strategis-from the top downdimulai dengan pemahaman yang jelas tentang hasil bisnis yang diinginkan dan berkembang menjadi deskripsi rinci tentang tugas-tugas penting dan milestones serta peran kunci dan tanggung jawab.

Pembuatan business case terdiri dari 8 tahap yaitu:

1. Membuat fact sheet dengan data relevan dan melakukan analisis data yang meliputi hal-hal berikut:

2. Analisis keselarasan.

3. Analisis manfaat keuangan.

4. Analisis manfaat non-keuangan.

5. Analisis resiko, yang dihasilkan dari:

6. Penilaian/penaksiran dan optimalisasi hasil/resiko yang dihasilkan oleh investasi TI, yang dinyatakan oleh:

7. Pencatatan secara terstruktur atas hasil-hasil dari tahap sebelumnya dan dokumentasi business case, serta hasil akhir yang selalu diperbaharui dengan cara:

8. Melakukan evaluasi business case selama eksekusi program, di seluruh siklus hidup program tersebut.

Setiap aktivitas utama tersebut mempunyai sekumpulan komponen yang sangat penting untuk mengevaluasi business case secara menyeluruh. Komponenkomponen tersebut bersama-sama membangun dasar untuk model analisis sebagai berikut:

\section{a. Outcomes}

Hasil yang jelas dan terukur, termasuk hasil antara (intermediate/leading), yaitu hasil-hasil yang diperlukan tetapi tidak cukup untuk mencapat manfaat akhir, dan hasil akhir (lagging) yang merupakan manfaat akhir yang harus diwujudkan. Manfaat ini dapat berupa keuangan maupun non keuangan.

b. Initiatives 
Bisnis, proses bisnis, orang (people), teknologi dan organisasi dari kegiatan proyek (termasuk proses membangun, implementasi, pengoperasian dan penghentian / retire) yang berkontribusi terhadap satu atau beberapa hasil.

c. Contributions

Kontribusi yang terukur yang diharapkan dari inisiatif atau hasil antara ke inisiatif atau hasil antara lainnya.

d. Assumptions

Hipotesis yang berhubungan dengan kondisi yang diperlukan untuk mewujudkan hasil atau inisiatif, dimana program organisasi tidak terlalu banyak bisa mengawasi kondisi tersebut. Penilaian atas resiko (risk assessment), yang dinyatakan dengan asumsi dan berbagai batasan lainnya seperti pertimbangan biaya, manfaat dan keselarasan, merupakan bagian utama pada proses business case.

Dalam beberapa kasus, program investasi TI akan dihentikan setelah menyelesaikan semua aktivitas dalam perencanaan program dan hasil yang diinginkan tercapai (gambar 2). Pada umumnya keuntungan dan nilai investasi yang diharapkan seperti tertera dalam business case, tidak akan terealisasi beberapa waktu lamanya, hanya pada saat itu program investasi dan juga business case terbukti menyampaikan hasil yang diinginkan.

Walaupun waktu pelaksanaan investasi dan penutupan business case berbeda pada setiap organisasi dan investasi yang beragam, sangat penting untuk memahami siklus hidup dari keputusan investasi seperti diilustrasikan pada gambar 3 berikut :

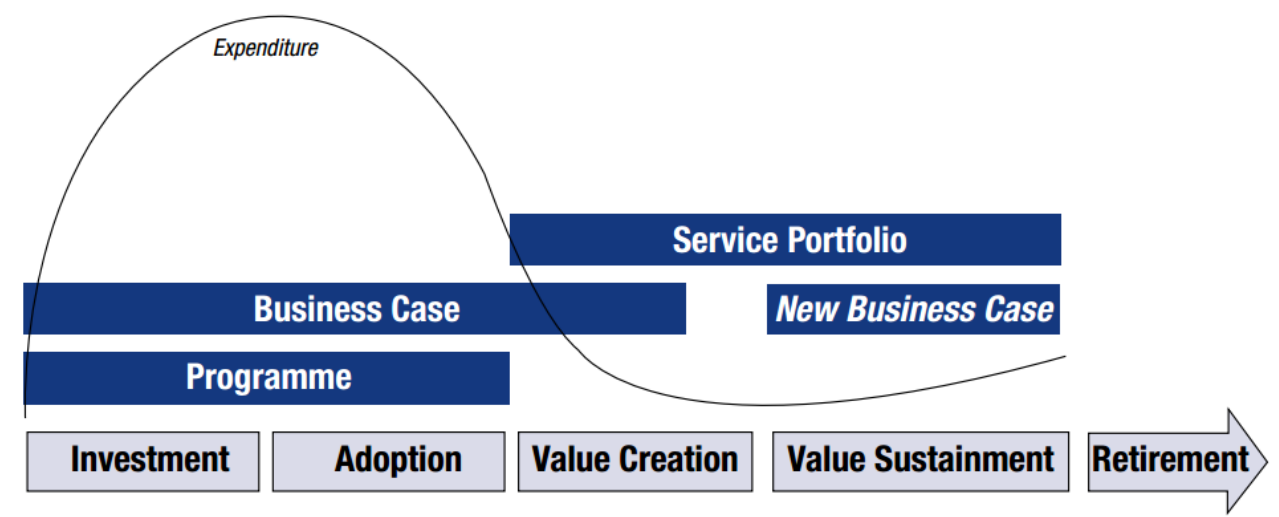

Gambar 3. Full Economic Life Cycle sebuah investasi (Sumber : The Business Case Guide: Using Val IT 2.0, 2010:12)

Proses adalah kumpulan kegiatan yang berinteraksi dan dilakukan sesuai dengan manajemen praktis. Proses mengambil input dari satu atau lebih sumber (termasuk proses lainnya), memanipulasi input, memanfaatkan sumber daya sesuai dengan kebijakan, dan menghasilkan output (termasuk output ke proses lainnya). Proses harus memiliki alasan bisnis yang jelas untuk dilaksanakan, pelaksana proses yang akuntabel, peran yang jelas dan tanggung jawab yang ada saat pelaksanaan setiap proses, dan sarana untuk melakukan dan mengukur kinerja. 
Domain dan proses Val IT diilustrasikan pada Gambar 4.

\begin{tabular}{|c|c|c|c|}
\hline \multirow[b]{2}{*}{ Value Governance (VG) } & $\begin{array}{l}\text { Establish informed and } \\
\text { committed leadership. }\end{array}$ & $\begin{array}{c}\text { Define and } \\
\text { implement processes. }\end{array}$ & Define portfolio characteristics \\
\hline & $\begin{array}{l}\text { Align and integrate value } \\
\text { management with enterprise } \\
\text { financial planning. }\end{array}$ & $\begin{array}{l}\text { Establish effective } \\
\text { governance monitoring. }\end{array}$ & $\begin{array}{c}\text { Continuously improve } \\
\text { value management practices. }\end{array}$ \\
\hline \multirow[b]{2}{*}{ Portfolio Management (PM) } & $\begin{array}{l}\text { Establish strategic direction } \\
\text { and target investment mix. }\end{array}$ & $\begin{array}{l}\text { Determine the availability and } \\
\text { sources of funds. }\end{array}$ & $\begin{array}{l}\text { Manage the availability } \\
\text { of human resources. }\end{array}$ \\
\hline & $\begin{array}{l}\text { Evaluate and select } \\
\text { programmes to fund. }\end{array}$ & $\begin{array}{l}\text { Monitor and report } \\
\text { on investment } \\
\text { portfolio performance. }\end{array}$ & $\begin{array}{l}\text { Optimise investment } \\
\text { portfolio performance. }\end{array}$ \\
\hline \multirow[b]{3}{*}{$\begin{array}{l}\text { Investment } \\
\text { Management (IM) }\end{array}$} & $\begin{array}{l}\text { Understand the candidate } \\
\text { programme and } \\
\text { implementation options. }\end{array}$ & Develop the programme plan. & $\begin{array}{l}\text { Develop full life-cycle } \\
\text { costs and benefits. }\end{array}$ \\
\hline & $\begin{array}{l}\text { Develop the detailed candidate } \\
\text { programme business case. }\end{array}$ & $\begin{array}{l}\text { Launch and manage } \\
\text { the programme. }\end{array}$ & $\begin{array}{l}\text { Update operational } \\
\text { IT portfolios. }\end{array}$ \\
\hline & Update the business case. & $\begin{array}{l}\text { Monitor and report on } \\
\text { the programme. }\end{array}$ & Retire the programme. \\
\hline
\end{tabular}

Gambar 4. Domain dan proses dalam Val IT

(Sumber : Val IT Framework 2.0 Extract, 2008:21)

Hubungan antara domain dan proses Val IT digambarkan sebagai berikut dan diilustrasikan pada Gambar 5. Perlu dicatat bahwa, meskipun dengan kebutuhan domain dan proses disajikan secara berurutan, hal itu tidak berarti bahwa setiap proses mengikuti dari proses pendahulunya. Meskipun secara logika untuk beberapa urutan, banyak proses dan key manajement praktis harus diikuti baik secara paralel dan iteratif. Tergantung pada sifat, ruang lingkup, ukuran dan dampak dari investasi, proses tertentu dapat diulang beberapa kali dengan review stage-gate setelah setiap iterasi. 


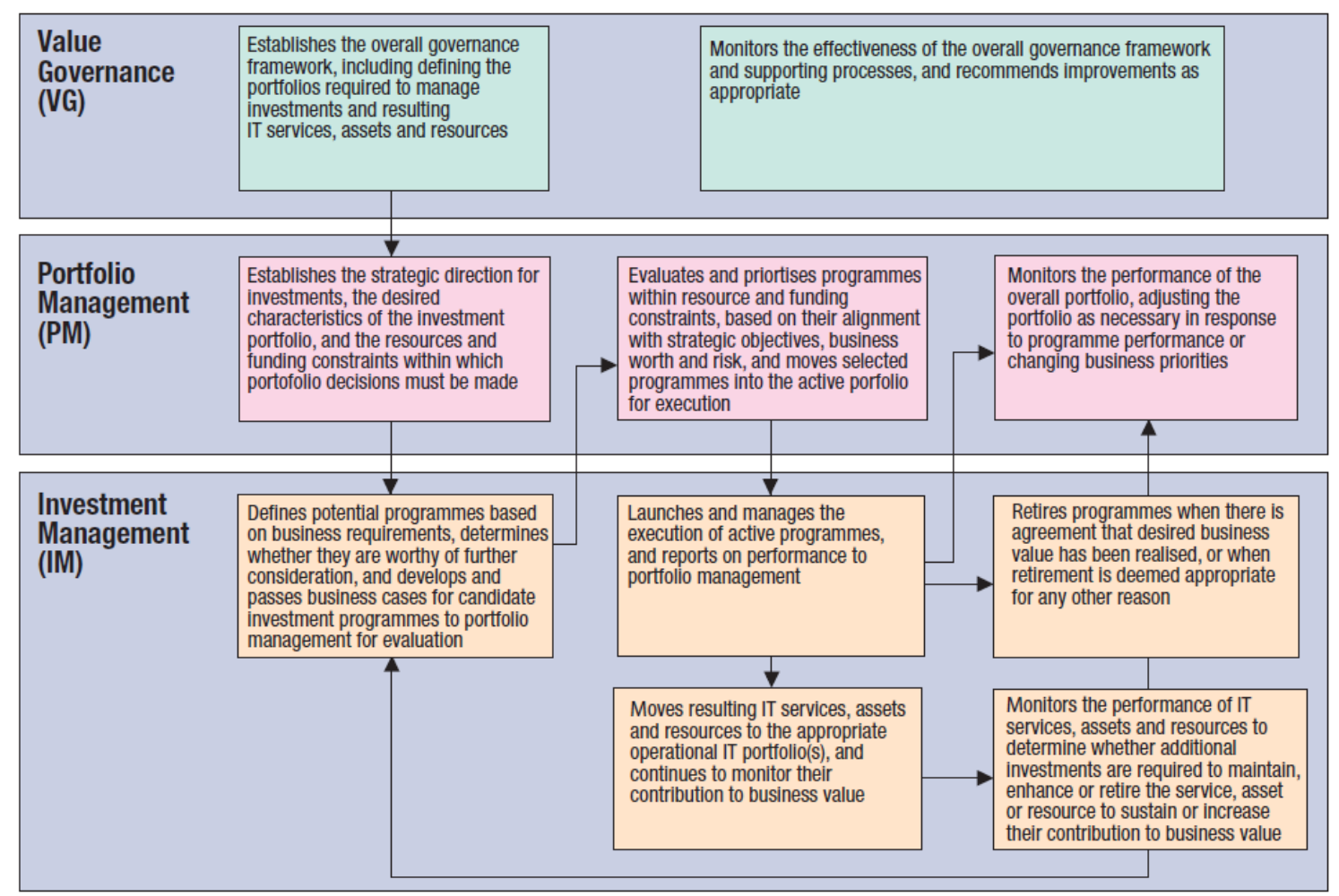

Gambar 5. Hubungan antara domain dan proses dalam Val IT (Sumber : Val IT Framework 2.0 Extract, 2008:22)

\section{Kesimpulan}

Dari kajian literatur mengenai kerangka kerja Val IT 2.0 maka dapat disimpulkan bahwa Val IT mengintegrasikan seperangkat prinsip yang praktis dan tata kelola yang terbukti, proses, cara pelaksanaan dan pedoman pendukung yang membantu tim manajemen eksekutif dan pemimpin organisasi lainnya mengoptimalkan realisasi nilai dari investasi berbasis TI. Proses yang terbukti dan tata kelola praktis dalam Val IT disajikan sebagai kerangka tata kelola terintegrasi yang menyediakan pembuat keputusan bisnis dan TI dengan pendekatan yang komprehensif, konsisten dan koheren untuk menciptakan hasil nyata dan nilai bisnis yang terukur.

\section{Daftar Pustaka}

[1] Benaroch and R. Kauffman, "A Case for Using Options Pricing Analysis To Evaluate Information Technology Project Investments," Information Systems Research 10 (March 1999): 70-86; and A. Taudes, M. Feurstein and A. Mild, "Options Analysis of Software Platform Decisions: A Case Study,” MIS Quarterly 24 (June 2000).

[2] Demirhan, Didem, Varghese S Jacob and Srinivasan Raghunathan.. Vol.22, Iss.3; pg.321. Journal of Management Information Systems, ProQuest Journal, Winter 2005-2006

[3] E.K. Clemons, "Evaluating Strategic Investments in Information Systems," Communications of the ACM 34 (January 1991): 22-36; M. 
[4] Harries, Sarah and Peter Harrison, CGE IT, FCP A, Five Critical Success Factors for Introducing Val IT, ISACA Journal, 2009

[5] ISACA, The Business Case Guide: using Val IT 2.0, the United States of America, 2010

[6] IT Governance Institute, Enterprise Value: Governance of IT Investments, The Val IT Framework 2.0 Extract, the United States of America, July, 2008

[7] Kadir, Abdul,dan Terra Ch. Triwahyuni. Pengenalan Teknologi Informasi. Andi. Yogyakarta, 2003.

[8] Smith, Heather A., James D. McKeen and Satyendra Singh, Developing Information Technology Strategy for Business Value, Journal of Information Technology Management Volume XVIII, Number1, 2007

[9] Thorp, John, CMC, I.S.P., The Val IT Story, ISACA Journal Online, 2006, www.isaca.org, diakses tanggal 29 Mei 2014

[10] Thorp, John, The Information Paradox - Realizing the Business Benefits of Information Technology, written jointly with Fujitsu, McGraw-Hill, Canada, first published in 1998 and revised in 2003. 